\title{
Relationship between Learning Environment and Teamwork Skills among Final Year Students of Vocational Colleges
}

\author{
Martini Mohammad, Abdullah Mat Rashid* \\ Department of Science and Technical Education, Faculty of Educational Studies, Universiti Putra Malay sia, Malay sia
}

Received October 27, 2019; Revised December 2, 2019; Accepted December 24, 2019

Copyright $\odot 2020$ by authors, all rights reserved. Authors agree that this article remains permanently open access under the terms of the Creative Commons Attribution License 4.0 International License

\begin{abstract}
Teamwork skills are one of the soft skills prioritised by employers when recruiting employees. In fact, lack of teamwork skills among new graduates will affect hiring for job. This article is intended to study the influence of the learning environment based on the perception of the relationship among students and the relationship between student and teacher on the teamwork skills among final year students in vocational college in Malaysia. The correlational design was utilized for this study which involved 241 final year students as respondents. All respondents were randomly selected from six vocational colleges in the State of Selangor, Malaysia. Questionnaires were used to collect research data. Finding shows that the respondents' level of tea mwork skills is high. Finding also reveals that respondents' perception on the relationship among students and the relationship between student and teacher shows a positive learning environ ment. Furthermore, finding also shows the learning environ ment based on the relationship among students and the relationship between student and teacher that are able to provide a positive relationship that contributes to the increase of teamwork skills among students at vocational colleges.
\end{abstract}

Keywords Technical and Vocational Education and Training, Malaysian Vocational Diploma, Vocational College Curriculum Standard, Relationship among Students, Relationship between Students and Teachers

\section{Introduction}

Employers emphasized teamwork skills are a must possessed by employees and have become the main criteria viewed by employers in selecting new employees (National Association of College and Employers, 2017;
National Association of College and Employers, 2018). The Job Outlook Survey 2016 report shows that teamwork skills are listed as among the top three employability skills given attention by employers in choosing new employees (National Association of College and Employers, 2016). Among benefits to employers is helping strengthen the company towards achieving its goals through maximising the skills and talent of each me mber of the team (Zulhamri, Mohammad Shattar, Samir, Paramsivam, Aidy \& Azali, 2010).

Deal and Kennedy (2000) found out that there is significant difference on size of company in organization culture, such as attitude and behavior in the workplace. A finding from Saari and Rashid (2013a) shows that a program is called the National DualTrain ing System where the apprentices attached with industries multinational company are more likely to have better teamwork skills compared to their colleagues attached with government link companies as well as small and medium size companies. Multinational companies and government link companies have better learning environment compared to small and medium companies. A multinational company provides systematic training method, curriculum content, excellent tools and equipment and high-quality supervision (Saari \& Rashid, 2013b). In addition, multinational companies also create environment that flourishes team work in the workplace. However, the result shows that the type of company can correctly estimate about 46 percent of graduates who would get a job offer.

Fraser (1998) defines learning environ ment as context of social, psychological and pedagogy where learning takes place that affects the student's attitude and achievement. Meanwhile, Fraser, Anderson and Walberg (1982) explained that the learning environment encompasses special characteristics of class group profiles that can be measured. Those characteristics are relationship among students, relationship between student and teacher, 
relationship between student and the subject being studied and the learning method and finally relate to the characteristics of the class structure. Hence the learning environment is not merely a physical space, but in fact contains various sources of information and materials, involves interactions, relationships between and among students and teachers as well as expectations and rules for learning and behaviour(Aladejana \& Aderibigbe, 2007).

\subsection{Teamwork Skills and Leaning Environment}

A teamwork skill is an important set of skills that can be developed in each student. It is a skill set that is used by every individual in a team towards group achievement or success (Richard \& Steven, 2011) and is identified as a transferable skill (Aifaa Husna, 2016). A teamwork skill is required for every new employee to ensure that they can work together in a team, share ideas and skills towards achieving the goals of the organisation. Therefore, it is not too obvious to state that a teamwork skill will influence the success of an organisation since each organisation comprises different individuals who have different characters and skills which contribute to the diversity of ideas in a team.

According to Kelchner(2013), maximising diversity in a team is important to enable different skills and ideas to be consolidated towards obtaining the best solution to achieve group objective. As such, apart from having academic qualifications and good technical skills, graduates must possess teamwork skills before stepping into the world of work. Good academic qualifications as well as stable technical skills do not guarantee a bright employment opportunity if the graduate does not have good teamwork skills. This is because teamwork skills are very much prioritised by employers nowadays when selecting their employees (Rosima, Mohd Izham \& Nora, 2013; Zafir, Ishak \& Abd. Hair, 2015). Having this skill in the employees, the talent and skills of the members of the organisation can be maximised, helping to strengthen the organisation (Zulhamri et al., 2010) as well as smoothen the management of the organisation (Mohd Yusof et al., 2013).

On the other hand, research shows that learning environment has an impact on the development of the student in physical, intellectual, emotional and social aspects which would then contribute to the productivity and hone teamwork skills. Rabiner, Godwin and Dodge (2016) state that an individual's social skills are among the predictors of academic achieve ment. Good social skills can build effective interaction between student, teacher and study contents and subsequently be able to influence the student's educational achievement. Effective interaction that exists among students would then be able to contribute to teamwork skills.

It is a necessity for every educational institution to ensure that the learning environment is managed properly.
This is to ensure that students are able to determine their personal goal, are active in collecting and managing the information required, controlling and assessing self-learning and are subsequently able to provide feedback on personal experience in various environments and contexts of teaching and learning. Dunkin and Biddle (1974) suggested the role of environment in learning can influence student behaviour in the classroom and therefore their achievement in studies. The environment such as family, friends, community, technological facilities, the institutional environment and teachers are elements identified as influencing an individual's development.

\subsection{Relationship among Students}

Interactions between student and a learning community whether through communication and cooperation in the daily learning process can create a close relationship between them. Smith and Bath (2006) defines learning community as a group of students in the context of learning that emphasises social interaction and cooperation among students. Social interaction and cooperation among students must be emphasised by the teachers through the teaching approach used. Learning that is student-centred can further improve social interaction and cooperation among them, as individuals will understand the learning materials and generate better behaviour when they are involved in an active learning environment. According to Virtanen, Tynjala and Etelapelto (2014), close cooperation among students can generate a more effective learning process as individuals will understand the learning materials and generate better behaviour when they are involved in a learning environment which is active. Whereas Fraser et al., (1982) states that the dimension of relationship among students is the relationship that encompasses the aspect of cooperation and disputes among classmates. This means that a good relationship can be obtained through good cooperation among the students and vice versa.

Hence the peer factor in the learning community is very important in the student learn ing process and in influencing student demeanour. Friends are the individuals that they often meet and communicate with in daily activities during the school session. All the joys and sorrows throughout the schooling session are shared together. Therefore, peers are the individuals who are very close among students apart from family members. Past research has shown that peers can improve the positive or negative behaviour among students (Cook, Deng, \& Morgano, 2007; Janosz, Archambault, Morizot, \& Pagani, 2008; Nelson \& De Backer, 2008; Simons Morton \& Chen, 2009; Saedah, Farazila, Mohd Ridhuan, Zaharah, Nuru lrabihah, Ahmad Arifin \& Azmi, 2016). According to Robert, Bridget and Joseph (2012), a good friendship among peers especially classmates can provide motivation towards developing the spirit of close cooperation among students in school. 
Furthermore, Nursuhaili (2010) stated that apart from developing abilities and social skills, peers also influence an individual's attitude and behaviour.

\subsection{Relationship between Student and Teacher}

The relationship between student and teacher refers to the extent of the demeanour that the student displays to the teacher. A close relationship between the two can be seen when the teacher and the student accept one another, are friendly, respect one another, cooperate, understand and considerate to one another or otherwise. According to Fraser et al., (1982) the relationship between student and teacher includes the extent to which the student's demeanour towards the teacher is guided by formal regulations such as the democracy factor, informalities and partisanship. The student's positive demeanour towards teacher is driven by a good relationship between the teacher and the student. The study carried out by Warwas and Helm (2017) found that, there exists a positive relationship between the characteristics of teaching executed by the teacher and the enjoyment of learning among the students. The positive relationship created by a teacher and his students is the most important aspect in encouraging positive development of the student and which will then be able to create a social environment which is more friendly and caring (Robert et al., 2012). Mikkonen, Pylvas, Rintala, Nokelainen and Postareff (2017) state that proper guidance given by the learning community such as teachers especially can encourage positive attitudes among the students such as being responsible and eager for the opportunity to advance further in studies.

Therefore, teachers must build a close relationship with their students as this relationship also influences the student to adapt in class, perform learning activities well and also to interact and cooperate with other students. Karner and Kogler (2016) state that a student's emotions and motivation for learning are influenced by the learning situation in class where the teaching encompasses learning methods used and involves teacher-student interaction. According to Norzanah (2012), a close relationship between the teacher and student can influence the student's cognitive and social emotions and henceforth student achievement. Through this close relationship the student is motivated to be actively involved in learning and therefore drive positive demeanour towards the teacher. Wentzel (2009) states that a good quality relationship between teacher and student is able to support the emotional development of a student well, build positive attitude, and motivate to achieve acade mic results and also to obtain true social skills. Whereas Klem and Connell (2004) state that when a teacher tries to make the learning process more interesting, encouraging communication among students, honest and treating them fairly are concerned. The student will respond by showing behaviour that is more positive in the classroom.

Research carried out in Malaysia has proven that the teacher factor is significant in influencing the academic performance and shaping the personality of the student (How, 2007; Rodiah, 2008; Rohani, Hazri \& Nordin, 2010; Che Nidzam, Saidatul Ainoor \& Asmayati, 2016). This means that the demeanour shown by the student indirectly is a result of the characteristic of teacher quality. Teachers must have the expertise in the field that is being taught, wise in diversifying lessons, and also have a personality that can be an example to the students. The practice of interesting learning covers creativity during the teaching process so that the students do not lose focus and involve themselves in learning (Muhamad Zaki, Razali, Azman \& Mohd As'ed, 2013). Siti Mistima and Efendi (2010) states that an approachable teacher, able to diversify the activities in class, provides clear explanation and is fair in assessing and is able to change student behaviour.

\section{Methodology}

This study mainly aims at investigating relationship between the learning environment and teamwork skills among final year students in diplo ma program at vocational colleges. Specifically, the formu late research questions are as follows:

1. Is there a significant relationship between the learning environment based on the perception of the relationship among students with the teamwork skills?

2. Is there a significant re lationship between the learning environment based on the perception of relationship between teacher and student with the teamwork skills?

This study employed a correlational research design using a set of self-reported questionnaires which consisted of two parts. The first part of the questionnaire contained 30 items which were assessed on a four-point Likert scale ranging from strongly disagree (1) to strongly agree (4), where the respondents rated their learning environment. These items were adapted and translated to fit the Malaysian context of learning environment based on the Learn ing Environment Inventory developed by Fraseret al. (1982). It also contained open-ended items to provide respondents with fle xibility in adding their perceptions for data enrichment. The second part of the questionnaire contained 30 items which were also assessed on a four-point Likert scale ranging from strongly disagree (1) to strongly agree (4), where the respondents rated their teamwork skills. These items were developed by the researchers based on Soft Skills Module for Malaysian Higher Education Institution (2006).

The instrument was validated by an expert in the area and pilot test that was conducted to ensure the instrument construction was clear and appropriate to assess the 
variables in this study. All of the information derived was then utilized to establish the valid ity while Cronbach Alpha reliability statistic was used to assess internal consistency of the instrument. The obtained Cronbach Alpha for reliability coefficient of .87 was later used to collect data from selected respondents.

This study used two stages sampling procedure to select respondents. Firstly, the researchers randomly selected 6 out of 8 vocational colleges in the state of Selangor. The total of samples is 285 respondents who were randomly selected from 1,100 final years' students of selected vocational colleges.

The response rate is $85 \%$ from 285 distributed questionnaires. The data obtained was analyzed with descriptive statistics (frequency, percentage and mean) and inferential statistics (Pears on correlation) using IBM SPSS software program at significant level of $p=.05$.

\section{Findings and Discussion}

\subsection{Self-Reported Teamwork Skills}

The finding shows that the respondent reported their teamwork skills as likely high with a mean score of 3.30 and a standard deviation of 0.31 . Respondents agreed that they are able to build good relationships, interact with others and work effectively with them to achieve the same objective. Respondents were found to be encouraging and built good relationships with various ethnicities in achieving the group objective. Respondents also suggested that diverse religions and races among them were not as an obstruction for them to work together to achieve the group goal. This is one of the most important characteristics of teamwork. Every individual in the group has to be positive in ensuring that the goal of an organisation can be successfully achieved. Zulhamri et al. (2010) stated that there are four major characteristics of teamwork which are collective effort, cooperation, positive and complementing one another. A positive characteristic can be explained when every member of the organisation must view teamwork as an opportunity to achieve goals, fulfil living requirements and provide support during a time of crisis.

The finding then shows that the respondents are able to understand and take turns in assuming the role as the leader of the group and as a member of the group. Respondents were found to be confident to become a leader if given the opportunity and show tolerance among group members when choosing the best leader from among them. Understanding each other's roles and functions is a collective effort that is one of the main characteristics of teamwork. According to Zulhamri et al., (2010) the collective effort characteristic is when members of the organisation must understand one another and share their views on the direction and goal that the members of the group want to achieve. Every member must also realise their own role and function as this attitude can provide motivation for each member to take part in every plan and action that has been decided.

The research findings also show that the final year students have the ability to identify and respect attitude, behaviour and belief of others. Respondents were found to be concerned over colleagues' behaviour and did not have negative preconception on different attitudes of colleagues. Trust is an important requirement in teamwork as without trust the possibility of conflict increases. This will cause the individuals involved not to build good relationships and to be unable to work effectively as a team. Therefore, trust is the key to maintaining a good working relationship among members of the group. According to Tuckman's theory (1965) consensus and respect for one another is at level three which is norming in the process of forming teamwork. At this level members of the team are clear on their own roles and responsibilities and begin to respect one another and would always have a consensus towards the decisions made by the group. It is also at this level that trust between one another begins to form.

\subsection{Learning Environment Based on the Perception of Relationship among Students}

Overall, the mean score and standard deviation of the learning environment based on the perception of relationship among students is $M=3.12, S . D=0.30$. The highest mean is for the item "I enjoy working with friends regardless of race" where $2(0.8 \%)$ students answered "Strongly disagree", 10 (4.1\%) answered "Disagree", $114(47.3 \%)$ answered "Agree" and 115(47.7\%) answered "strongly agree". This finding explains that final year students are flexible to work with anyone to execute a task where overall $95 \%$ of the students enjoyed working with friends regardless of race. This finding is supported by the item statement "I am flexible to work with anyone even though of different gender" where only $9.9 \%$ of students did not support the item and also through the item statement "I am flexible to work with friends in the same class or different class" where $89.7 \%$ of the respondents supported the item. In addition, it was found that $96.3 \%$ of the respondents agreed that they were mindful about the aspect of maintaining communication relationship among friends. This can be seen through the item "I look at my friend when I communicate with him" which is the second highest mean $(M=3.40$, S.D $=0.56)$.

The lowest Mean $(M=1.65, S . D=0.67)$ for the item "I do not like to be disturbed by classmates during learning sessions" where $110(45.6 \%)$ respondents answered "strongly disagree", 108(44.8\%) answered "Disagree", $21(8.7 \%)$ answered "Agree" and 2(0.8\%) answered "strongly agree". This finding shows that there exists a very close relationship from the as pect of cooperation and tolerance among the final year students of the Vocational College where almost all of the students, which is $90.4 \%$ 
who do not support the item. This finding is supported by the item statement "I assist classmates who are facing difficulties/problems while doing practical" and item "I actively discuss with friends during the learning activity in class/workshop" where $89.7 \%$ of the respondents supported those items.

The learning environment based on the perception of relationship among students shows that there exists a close relationship in the aspects of cooperation, communication and tolerance among the final year students of the Diploma programme. The researcher observed that there existed a situation where there is closeness in terms of cooperation, communication and tolerance among the final year students of the Diploma programme due to the learning environment which involved active involvement of the students.

Learning which is centred on the student involves the active involvement of students. Teachers have the role as a facilitator to help students develop understanding, build self-motivation, concept and knowledge (Holt \& Kysilka, 2006). One of the learning that is student-centred is through cooperative learning. Cooperative learning requires the students to work in s mall groups to complete a project or assignment together. Hence students will work together as a team not only to learn but also to help one another to achieve the same objective. According to Johnson and Johnson (1999), cooperative learning will not happen if only one person cares and does the task in a discussion group whereas the other members act only as a passenger. Therefore, cooperative learning requires the active involvement of the student. According to Bruner (1986), through an active learning environment, students will complement each other in achieving the objective through the spirit of cooperation and social interaction between one another. Students are given the freedom to discuss, question, work together in the learning process whereas the role of the teacher is if more as a facilitator, mentor, coach, moderator and enabler towards the learning process (Eggen \& Kauchak, 2012).

Final year students are also found to be flexible in working with anyone even though of different gender and different race. The researcher also noticed this would happen through the imple mentation of cooperative learning. According to Kagan (1992) among the benefits of cooperative learning for students is that the members of different groups can work together towards achieving the same goal and creating a positive interdependency. Hence the difference in gender or race is not an obstruction in achieving the group goal. Apart from that, the differences in opinions presented by members of a heterogeneous group can provide realisation to me mbers of the group that there are opinions which are different from their own.

\subsection{Learning Environment Based on the Perception of Relationship between Student and Teacher}

Overall, the mean score and standard deviation is $M=$
$3.32, S . D=0.36$. The lowest mean is $(M=3.12, S . D=0.67)$ for the item "I do not delay the assignment given by the teacher" where $4(1.7 \%)$ students answered "strongly disagree", 29(12.0\%) answered "Disagree", 143(59.3\%) answered "Agree" and 65(27.0\%) answered "strongly agree". This finding shows that the majority of students follow the teacher's instructions to complete the task given within the time period set. The highest mean is $M=3.52$, $S . D=0.53$ for the item "I use the appropriate intonation of voice when communicating with the teacher" where $1(0.4 \%)$ students answered "strongly disagree", $1(0.4 \%)$ answered "disagree", 110(45.6\%) answered "Agree" and $129(53.5 \%)$ answered "strongly agree". This finding explains that the final year students protect their relationship with their teacher through a positive demeanour especially when communicating. This finding is supported by the item statement "I look at my teacher when I communicate with him" which is the second highest mean $(M=3.46, S . D=0.55)$ where only $2.1 \%$ respondents did not support that item. The analysis also shows that the final year students have the attitude of respecting their teacher. This can be seen through the item statement "I request permission from the teacher to use the facilities in the workshop" which is the third highest mean $(M=3.44$, $S . D=0.59)$ where $95.9 \%$ respondents supported the item. In addition $90.5 \%$ respondents agree that they would shake hands with the teacher once the learning session ends.

Finding shows that the final year students of the diploma program protect their relationship with their teachers by positive demeanours shown especially when communicating. Respondents are found to use the appropriate voice intonation when communicating with their teachers and look at the teacher when communicating. Good communication between the student and teacher can create a learning environment which is conducive that will then encourage the student to be more committed to learn. Respondents were also found to request permission from the teacher to use the facilities in the workshop, assist the teacher to tidy up the workshop after practical work, acknowledge teacher when they meet and are excited to learn knowledge and new skills from teacher. Positive demeanours shown by students reflect a learning environment that is positive from the perception of relationship between student and teacher. Teachers play an important role in creating a positive learning environment based on the perception of relationship between student and teacher. According to Klem and Connell (2004), when the teacher works hard to make the learning process more interesting, encourages communication among students, treats them fairly as well, and is concerned, honest students will then respond by showing more positive behaviours.

The findings of the research also found that the majority of the final year students of the Diplo ma programme give good cooperation and commitment to complete the tasks assigned by teacher. Respondents were found not to delay the tasks given by teacher. The researcher also observed 
that this situation happens as a result of the quality of teachers of the Vocational College itself. Mikkonen et al., (2017) states that good guidance given by the learning community such as teachers specifically can encourage a positive attitude among the students such as being responsible and eager for the opportunity to advance in learning. A high level of concern by the teacher is able to encourage the students to be actively involved in the learning activity (Patricia \& Tak, 2011), pay attention to teacher's instructions and be more respectful towards teacher (Rohani et al., 2010).

The student's active involvement in the learn ing activity can hone social skills such as teamwork skills. Norzanah (2012) stated that a close relationship between teacher and student can influence cognitive, social and emotions of the student as well as student involvement in the learning process. Findings of past research have also shown that there exists a positive relationship between the characteristic of the quality of teachers studied with the learning commitment of students. This means that the quality characteristic found in teachers influences the student commitment to learn (Good \& Brophy, 2008; Rohani et al., 2010). In addition, Fatimah (2010) states that the teacher's behaviour when in the presence of students can improve student involvement in the learning activity.

\subsection{Relationship between Learning Environment and Teamwork Skills}

Referring to Table 1, there is a significant positive association between the relationship among students and teamwork skills $(r=0.526, p<0.01)$ and relationship between the relationship between student and teacher with teamwork skills $(r=0.571, p<0.01)$. All these association are strong (Cohen, 1988). These show that the learning environment based on the perception of relationship among final year students and relationship between student and teacher has a strong positive relationship with the student's teamwork skills.

Table 1. Pearson Correlation for Relationship of Learning Environment with Teamwork Skills

\begin{tabular}{|c|c|c|c|}
\hline & Teamwork Skill & Mean & s.d. \\
\hline Relationship among Students & 0.526 & & \\
\hline $\begin{array}{c}\text { Relationship between } \\
\text { Students and Teachers }\end{array}$ & 0.571 & & \\
\hline
\end{tabular}

Findings show that there exists a strong positive relationship between the learning environment based on the perception of relationship among students and teamwork skills. This means that a positive learning environment based on the perception of relationship among students is able to provide a positive implication in contributing to the level of teamwork skills among the final year students of the Vocational College Diploma. Respondents in this research overall have shown that a positive learning environment is based on the perception of relationship among students where the finding reflects that there exists a close relationship from the aspects of cooperation, communication and tolerance among students. This positive relationship can hone and improve the level of teamwork skills among students. A learning environment where there is a positive relationship among peers is able to provide positive influence which drives towards improving the level of teamwork skills among students. According to Virtanen et al., (2014), close cooperation among students can generate a more effective learning process as the individual will understand the learning materials and generate much better behaviour when they are involved in a learning environ ment which is active. Meanwhile, Nursuhaili (2010) states that besides increasing abilities and social skills, peers also influence the attitude and behaviour of an individual.

Finding shows that there exists a positive relationship which is strong between the learning environment based on the perception of relationship between student and teacher with teamwork skills. This means a positive learning environment based on the perception of the relationship between student and teacher is able to have a positive influence to improve the level of teamwork skills among the final year students of the Vocational College Diploma programme. Respondents in this research overall have shown a positive learning environment based on the perception of relationship between student and teacher where the finding shows that there exists a good relationship from the aspects of cooperation, communication and tolerance between students and teachers. Respondents were found to cooperate with teachers when completing a task within the period set by the teacher and help teachers to tidy up the workshop after the practical learning session ends. They also look after the communication aspect by looking at the teacher when communicating with him and using the appropriate voice intonation when communicating with teacher and acknowledge teacher when they meet. Apart from that, respondents also respect the teacher by not asking questions before the teacher has finished explaining and asking for permission from the teacher before using the facilities in the workshop. Therefore, through these positive relationships, social skills can be obtained and refined which would then have a positive effect in improving teamwork skill. A good quality relationship between teacher and student can support the emotional development of a student well, build positive attitude, provide motivation in achieving academic results and als o obtain true social skills. (Wentzel, 2009; Saari \& Mat Rashid, 2013; Karner \& Kogler, 2016).

\section{Conclusions}

Final year students of the Vocational Diploma programme, Vocational College have a high level of 
teamwork skills. Respondents were found to be capable of building good relationships, interacting with others and working effectively with them to achieve the same objective, have the ability to understand and to take turns assuming the role of group leader and member of group and be able to identify and respect attitude, behaviour and belief of others. A learning environment based on the perception of relationship among students and student relationship with teacher found that there exists a positive environment which means that there exists a good relationship among students in the aspects of cooperation, communication and tolerance among students and students show a positive demeanour towards teachers. There is also a strong positive relationship between the learning environment based on the perception of relationship among students and relationship between student and teacher with the teamwork skills of the students. This finding implies that through a learning environment that is positive based on the perception of relationship among students and relationship between student and teacher it is able to have a positive influence in improving teamwork skills.

\section{REFERENCES}

[1] Aifaa Husna Asha'ri. (2016). Kemahiran Boleh Pindah Dalam Kalangan Pelajar Kejuruteraan di IPTA. Laporan Projek Sarjana Pendidikan Teknik dan Vokasional, Universiti Tun Hussein Onn Malaysia.

[2] Aladejana, F., \& Aderibigbe, O. (2007). Science laboratory environment and academic performance. Journal Science Educational Technology, 16, 500-506.

[3] Bruner, J. (1986). Actual Minds, Possible Worlds. Cambridge, MA: Harvard University Press.

[4] Che Nidzam Che Ahmad, Saidatul Ainoor Shaharim dan Asmayati Yahaya. (2016). Kesesuaian Persekitaran Pembelajaran, Interaksi Guru-Pelajar, Komitmen Belajar dan Keselesaan Pembelajaran Dalam Kalangan Pelajar Biologi. Jurnal Pendidikan Sains dan Matematik Malaysia, 6(1).

[5] Cook, T. D., Deng, Y., \& Morgano, E. (2007). Friendship influences during early adolescence: The special role of friends' grade point average. Journal of Research on Adolescence, 17, 325-356. DOI: 10.1007/978-1-4614-2018 $-7 \_17$

[6] Deal, T.E. \& Kennedy, A. A. (2000). Corporate cultures: The rites and rituals of corporate life. New York: Basic Books.

[7] Dunkin, M. J. and Biddle, B. J. (1974). The study of teaching. New York, NY: Holt, Rinehart \& Wisnton.

[8] Fatimah Harlina Mohd Taib. (2010). Hubungan tingkah laku kesediaan pensy arah dengan tahap motivasi pelajar, Jurnal Pendidikan Sains \& Matematik, pp. 1-10. Universiti Teknologi Malaysia.

[9] Fraser, B. J. (1998). Learning Environments Research. The
Birth of a New Journal: Editor's Introduction, 1, 1-5.

[10] Fraser, B. J., Anderson, G. J., \& Walberg, H. J. (1982). Assessment of learning environments: Manual for Learning Environment Inventory (LEI) and My Class Inventory (MCI) (3rd ed.). Perth, Australia: Western Australian Institute of Technology.

[11] Holt, L.C., \& Kysilka, M. (2006). Instructional Patterns: Strategies for Maximizing Student Learning, California: Sage Publication.

[12] How, L. C. (2007). Faktor-faktor yang Mempengaruhi Gejala Ponteng di kalangan Pelajar Sekolah Menengah. Tesis Sarjana, Universiti Teknologi Malay sia.

[13] Janosz, M., Archambault, I., Morizot, J., \& Pagani, L. S. (2008). School engagement trajectories and their differential predictive relations to dropout. Journal of Social Issues, 64, 21-40.

[14] Johnson, D. W., \& Johnson, R. T. (1999). Learning together and alone: Cooperative, competitive, and individualistic learning (4th ed.). Needham Heights, MA: Allyn and Bacon

[15] Kagan, S. (1992). Cooperative Learning Resources for Teachers. Riverside, CA: University of California at Riverside.

[16] Karner, T., \& Kogler, K. (2016). Emotional states during learning situations and students' self-regulation interactions in the vocational classroom. Journal of Emperical Research in Vocational Education and Training, 8(12).

[17] Kelchner, L. (2013). Strengths and weaknesses of cross-functional teams. Retrieved from:http://smallbusines s.chron.com/strengths-weaknesses-cross-functional-teams24653.html

[18] Klem, A.M., \& Connell, J.P. (2004). Engaging Youth in School. www.irre.org/publications/pdfs/Engaging_Youth_ 9-8-04.pdf.

[19] Mikkonen, S., Pylvas, L., Rintala, H., Nokelainen, P., dan Postareff, L. (2017). Guiding workplace learning in vocational education and training: a literature review, Journal of Emprical Research in Vocational Education and Training, 9(9).

[20] Muhamad Zaki, S., Razali, H., Azman, H, \& Mohd As'ed, S. (2013). Kreativiti Guru Dalam Pengajaran Mata Pelajaran Kemahiran Hidup, Prosiding Konvensyen Kebangsaan Pendidikan Guru, 1: Johor

[21] National Association of Colleges and Employers. (2016). Job Outlook Survey. Bethlehem, Pennsylvania: United States.

[22] National Association of Colleges and Employers. (2017). Job Outlook Survey. Bethlehem, Pennsylvania: United States.

[23] National Association of Colleges and Employers. (2018). Job Outlook Survey. Bethlehem, Pennsylvania: United States.

[24] Nelson, R. M., \& DeBacker, T. K. (2008). Achievement motivation in adolescents: The role of peer climate and best friends. The Journal of Experimental Education, 76, 170-189.

[25] Norzanah Abu Taib. (2012). Hubungan antara 
keterhubungan, kebolehsediaan dan komunikasi guru dengan ketrampilan pelajar aliran kemahiran, Tesis master, Universiti Putra Malay sia.

[26] Patricia, C. K., \& Tak, C.C. (2011). Teachers' and students' perceptions on teachers' caring behaviors. GERA-36th Annual Meeting (pp. 1-38). Coastal George Center, Avannah Geogia.

[27] Rabiner, D. L., Godwin, J., \& Dodge, K. A. (2016). Predicting Academic Achievement and Attainment: The Contribution of Early Academic Skills, Attention Difficulties, and Social Competence. School Psychology Review, 45(2), 250-267.

[28] Richard L.Hughes \& Steven K.Jones. (2011). Developing and assessing college student teamwork skills. New directions for institutional research. Wiley Periodical.Inc. (149), DOI: $10.1002 / \mathrm{Ir} .380$

[29] Richardson, J. T. (2005). Instruments for obtaining student feedback: a review of the literature. Assessment \& evaluation in higher education, 30(4), 387-415.

[30] Robert C. Pianta, Bridget K. Hamre, \& Joseph P. Allen. (2012). Teacher Student Relationships and Engagement: Conceptualizing, Measuring, and Improving the Capacity of Classroom Interactions. Handbook of Research on Student Engagement.

[31] Rohani Arbaa, Hazri Jamil \& Nordin Abd Razak. (2010). Hubungan Guru-Pelajar dan Kaitannya den gan Komitmen Belajar Pelajar: Adakah Guru Berkualiti Menghasilkan Perbezaan Pembelajaran antara Jantina Pelajar?. Jurnal Pendidikan Malay sia 35(2), 61-69.

[32] Rosima Alias, Mohd Izham Mohd Hamzah \& Nora Yahya. (2013). Keperluan Kemahiran Generik: Antara Aspirasi Majikan dengan Keperluan Pekerja Profesional. Jurnal Pengurusan 37, $105-114$.

[33] Saari, H.A. \& Rashid, A. M. (2013a). Competency level of employability skills among the apprentices of the national dual training system: A comparative analysis of industry perception by company status. The International Journal of Education and Research, 1(11), 1 - 20.

[34] Saari, H. A., \& Rashid, A. M. (2013b). Relationship between implementation of cooperative vocational edu cation and job offering among apprentice of national dual training sy stem in Malay sia. The Middle East Journal of Scientific Research, $18(11), 1578-1583$.

[35] Simons-Morton, B., \& Chen, R. (2009). Peer and parent influences on school en gagement among early adolescents. Journal of Youth and Society, 41, 3-25.

[36] Siti Mistima Maat \& Effandi Zakaria. (2010). The Learning Environment, Teacher's Factor and Students Attitude Towards Mathematics Amongst Engineering Technology Students. International Journal Of Academic Research. 2(2):16-20

[37] Smith, C. \& Bath, D. (2006). The Role of Learning Community in the Development of Discipline Knowledge and Generic Graduate Outcomes. Australia Higher Education, 51, 259-286.

[38] Tuckman, B. W. (1965). Development sequence in small groups. Psychological Bulletin, 63(6), 384-399. DOI

\subsection{7/h0022100.}

[39] Virtanen, A., Tynjala, P. dan Etela pelto, A. (2014). Factors promoting vocational students' learning at work: study on student experiences. Journal of Edu cation Work, 27(1), 4370 .

[40] Warwas, J., \& Helm, C. (2017). Enjoying working and learning in vocational education: A multilevel investigation of emotional crossover and contextual moderators. Journal of Emperical Research in Vocational Education and Training, 9(11).

[41] Wentzel, K. R. (2009). Student's Relationship With Teachers As Motivational Contextin Wentzel, K. R. \& Wigfield, A. Handbook of Motivation, (pp. 301-322). New York: Routledge Taylor \& Francis Group.

[42] Zafir Mohd Makhbul, Ishak Yussof \& Abd. Hair Awang. (2015). Antara realiti dan harapan-Kajian empirical persepsi majikan terhadap prestasi graduan tempatan. Malay sian Journal of Society and Space, 11(10), 27 - 36. 